\title{
Rethinking the Challenges of a Multilateral Development Bank in African Society: The African Development Bank in Nigeria, 1986-2015
}

\author{
Augustine Uche Igwe \& Festus Chibuike Onuegbu \\ http://dx.doi./org/10.4314/ujah.v20i2.1
}

\begin{abstract}
Multilateral development banks as international donor institutions, oftentimes, are wholly blamed for the failures they encounter in their operational activities in African society. Many scholars have harped on the bourgeois development approach of such banks to fault everything about their operation in Africa. However, a cursory look at the problems that confronted those multilateral development institutions in some African societies tended to present a different scenario. This paper, therefore, examines the challenges of the African Development Bank as one of the international donordevelopment institutions in Nigeria. Methodology wise, it adopted the qualitative method of research but, as a study in economic history, relevant data were presented and analysed. The writer drew his sources of information mainly from oral respondents, official policy documents and reports. Also, books, newspapers and magazines served as sources. The paper having adopted the structural functionalist theory as the relevant frame of analysis argues that not all the blame for failures about the Bank operation in Nigeria did originate from the Bank: both Nigeria as a recipient and the Bank as a donor share in the responsibility for the performance or failures that the Bank had recorded in the country. The paper found that contrary to the common belief that the African Development Bank is wholly responsible for the problems that confronted it in Nigeria most of those problematic challenges are inherent symptoms of a dysfunctional structure of the Nigerian society. It concludes that the
\end{abstract}


Bank has not been able to realise its developmental targets in Nigeria not because of its bourgeois approach to development but, largely, because the country's body-politic had been defectively structured in a way that often impedes development. It, thus, enjoins Nigerians not to wholly blame international institutions and donor agencies for all the development failures; hence, it recommends a workable framework and attitudinal reorientation for Nigeria to rid off its structural disabilities and understand her role in the spectrum of development agenda in a globalising world.

\section{Introduction}

The African Development Bank, since its inception in the early 1960s, had maintained a predictable line of relations with Nigeria as an important member-country. Though the relations were not very much robust in the first decade of the Bank's existence due to tilting challenges that had to confront it in its formative years, it began to witness tangible commitments after the end of the Nigeria-Biafra War. Fortunately, the country's civil war economic tensions could not last longer. By the run in of the mid 1970s Nigeria had entered into the 'oil boom era' as a result of the tripling oil prices in the world market. Aluko (1990) observes that the country's revenue base in the 1970s had quadrupled the prewar years, and the main exchange earner was petroleum exports as against agricultural exports. Nigeria, once again, looked like an economic power house in Africa within a short period of time. She, thus, began to make huge contributions and commitments to the African Development Bank and for Africa's development at large. There was a strong conviction on the part of the Bank that Nigeria could be more of a benefactor than a beneficiary, and would help enhance the Bank operations as Africa's premier development institution. It suffices to say that Nigeria before the 1980s had 
identified for itself the role of a benefactor in her relationship with the Bank which was largely explained by her growing economic fortune.

Surprisingly, the once economic buoyancy that Nigeria was known for after the civil war experience fizzled out in the face of torrential economic downturns that engulfed the country in the beginning of the 1980s. In 1986, Nigeria, in the face of economic recession and its concomitant tensions, rescinded her earlier decision not to make further borrowings from the African Development Bank, and the Bank began to extend new and several major lines of lending to the country. Going by the statistical report on lending operations in Nigeria as given in 1989 by the then Nigeria's Minister of Finance and Economic Planning, Dr Chu Okongwu, the AfDB concluded nine loans with Nigeria worth about \$761million between 1986 and 1989 (New Nigerian, May 1989). These loan operations were geared to make development impact on industry, agriculture, infrastructure and rural development, small scale enterprises, and export sector of the country's economy. Before the end of the 1990s, the Bank activities in the country had been extended to health, water supply, irrigation, and forestry projects in several States of the federation. The point is that Nigeria moved from being a benefactor to a big beneficiary of the Bank activities. In the first decade of the new century, so far, the Bank has meaningfully engaged agriculture and agricultural research, infrastructure, water and sanitation, healthcare development, private sector development, public finance management and economic reforms, vocational education, public-private partnership, and regional integration projects. In other words, the Bank has become a key player in the shaping of the Nigerian economy and society. It has identified for itself an important role in Nigeria's development cause. 
However, the African Development Bank in Nigeria has been confronted by myriad of constraining challenges; and there is seemingly a general consensus that the challenges were symptoms of failure of the Bank in Nigeria. It is against this backdrop that the paper examines what constitutes the challenges of the Bank in Nigeria, and who shares in the responsibility. The paper is divided into seven sections: introduction, theoretical framework, how the Bank operates, failures of the Bank in Nigeria, the external financial market and other principal donors in Nigeria, Nigerian society as the big suspect, and conclusion and the way forward.

\section{Theoretical Framework}

This paper is premised on the structural functionalist theory as the relevant frame of analysis. Structural functionalism is a theory that explains why a society functions the way it does by emphasizing on the relationship between the various social institutions that make up the society. The theory was developed by the writings of Talcott Parsons, Robert Merton, and Herbert Spencer on modern human society, and was later adapted by two American political scientists David Easton and Gabriel Almond. Structural functionalist theory assumes that every society has a complex system \{structure\} whose parts \{institutions\} work together to promote solidarity and stability that would guarantee development, a functional society (Mayhew, 1985; and Knapp, 1994). In a society where these institutions are not harmoniously working together, the structure is impaired and development becomes difficult as the society is dysfunctional. Thus, the success or/and failure of a society are largely dependent on the functionality of her basic structure.

According to Pope (1983), 'when the structural foundation of a society is inherently faulty, she manifests certain disabilities 
that will eventually impede the very development she seeks for. In other words, a defective internal structure of a society predicates defective development. Dibua (2006:21) posits that the internal political economy of many developing countries is weak and dysfunctional: a little shock in the international economy translates into bigger waves of crisis in their domestic economy. It does mean that the imparity of the internal structure of a society invariably makes events in the external environment decide the fate of her development. However, that is not to say that there are no externally induced causes to development failures in developing societies, rather the centrality of the structural functionalist argument lies in the fact that most of the causes are internally located in their basic structural formations. Thus, the failure of donor-development in a developing society, most times, is not so much about how the donor behaves but about the internal absorptive capacity of the recipient to make good of it.

The question before us then is how relevant is structural functionalist theory in explaining the cause of challenges that the African Development Bank has encountered in Nigeria? Placing Nigeria's development question on the structural functionalist theoretical lens, one would see that the structure of the Nigerian body-politic is defective and dysfunctional. The economy lacks proper diversification. It largely depends on crude oil \{petroleum exports and lacks efficient technology-driven industrial base. There is persistent poor capacity to produce locally which is terribly matched with high import dependence. There is, also, high incidence of public corruption, weak institutions, poor policy planning and execution, high inflation, civil strife and youth restiveness, and a host of other symptoms of structural deficiency. A situation such as this may hardly guarantee effective development, no matter where and who the development is coming 
from. The structural functionalist school, thus, tends to argue that most of the problematic challenges the African Development Bank faced in Nigeria were symptoms of a defective structure of the Nigerian society.

\section{How the Bank Operates}

The African Development Bank is primarily a multilateral development finance institution with a defined responsibility to facilitate economic development of member-countries. Article 1 and 2 of the Agreement Establishing the Bank (1998) state that: the purpose of the bank shall be to contribute to the economic and social progress of its members, individually and jointly... and to implement this purpose by carrying out a number of functions the bank shall seek to cooperate with national, sub-regional and regional development institutions. The same end, it shall cooperate with other international institutions and organizations pursuing a similar purpose concerned with the development of Africa.

The Bank, by implication, is guided in all its decisions and operations by these provisions in its agreement. It does not only seek the cooperation of interested domestic or national agencies but, also, international institutions in performing its functions. The Bank enters into the international capital market as a 'broker': it negotiates and mobilises international bilateral and multilateral loans on a minimal interest agreement lower than what is officially obtainable in international market, and extend to member-countries at concessional terms with long term repayment maturity. Suffice it to say that the extent of the Bank's operation in a regional member-country is largely dependent on the developments on the international money market which it has less control of. 
Fordwor (1981:3) notes that the African Development Bank allows the borrower-country to design project and programme priorities it wants her to fund. It is the responsibility of the borrowing country to prepare its project proposals; the Bank can only provide assistance in that direction if need arises. The Bank, thus, largely depends and had to work on what is proposed to it by a borrower-country, and had less input to make on the choice of projects made to it for funding. The Bank, also, can send supervisory missions or teams to monitor the progress of its funding activities in regional member-countries. By implication, the Bank ought to have a number of competent technical and field staff on ground in every member-country where it is funding certain projects. It is expected to provide for the Bank the required competence to do project appraisal, preparation, and performance and audit assessment.

Moreover, the African Development Bank operations in member-countries of Africa are mainly counterpart portfolios. Most of the projects and programmes are funded on counterpart basis. The recipient country is expected to provide certain percentage of the entire funding as part of the obligation it has to fulfill before it could access the Bank's lending. Apart from the counterpart funding from the beneficiary member-country, the Bank most times have other international donors that provide counterpart funding activities in member-countries of Africa. These other counterpart donors that the AfDB has to work with in providing lending for development projects in Africa are multilateral international institutions and /or bilateral foreign state agencies that had their different lending orientation and policies. Pitt (2010: 49), for instance, notes that the World Bank, United Nations agencies, European Bank, Arab Bank, United States Agency for International Development, Norway, Canada, Sweden, 
and China are known for their joint funding of projects with the African Development Bank in member-countries of Africa. The bank, thus, works with the complementation of other international donors to actualise its goals in any African economy.

It is against this backdrop that the African Development Bank's operations and challenges in Nigeria are contextualised. The pertinent questions are: 'is it justifiably proper to squarely rest all the blame on the bank for the failures it may have encountered in the course of its operation in Nigeria? Does the Nigerian state and society at large have a huge responsibility for the failures? How could the bank be made to fully actualise it development goals in Nigeria?

\section{Failures of the Bank in Nigeria}

One of the major problems with the African Development Bank in Nigeria was the delay in loans disbursement and project completion. The Bank had hardly made prompt and effective credit disbursement to most projects it embarked on within the period originally agreed. For example, it took the bank a long five years to begin disbursement of funds for its line of credit to National Economic Reconstruction Fund and more than eleven years to ensure its completion (New Nigerian, May 1998). From the Bank's operation statistics in Nigeria, one could observe that it took the bank average three to five years to begin disbursement of funds after a loan agreement was approved. It took the Bank between eight to twelve years to complete credit disbursement on a capital infrastructural project, if, eventually, it was not abandoned or cancelled; while a line of credit or non-project lending to an institution took the Bank between five to seven years to complete, if it did not get terminated along the line. The point is that the 
delays in credit disbursement in Nigeria by the Bank largely translate to poor project execution.

Moreover, the African Development Bank, unlike the World Bank and the European Union, respects and allows the borrowing country to design its development priorities and project proposals. The Bank, largely, depended on the choice of projects put forward to it by the borrowing member-country. It has always had little input in the choice of projects proposed to it for funding. In most cases, the process has compromised competent and viable assessment of project preparations. For example, the $\mathrm{A} f \mathrm{DB}$, in 2013 , approved a loan of $\$ 35.2$ million for Kano Mass Transit Scheme that could not even takeoff (AfDB Group, 2014:104). Knowing that the mainstay of Kano State economy revolves around agriculture, the Bank could have identified a number of abandoned farm irrigation projects once embarked on by the State Government as an important priority to fund if it had made a proper project viability assessment before lending. The implication is that the inability of the Bank to meaningfully participate in the determination of project choice proposed to it has made it to fund a number of wrong and even non-existing projects; and this has often hampered the effective operation of the AfDB in Nigeria. Similarly, there was infrequent and poor monitoring and supervision of projects by the Bank. One of the Project Evaluation Reports released by the Bank shows that 'out of 48 projects implemented by the AfDB in Nigeria between 1991 and 2009, 39 of them received less than one technical supervision mission per year; other nine of them were never supervised; and more than 68 per cent of the total number of the projects were poorly appraised (AfDB Group, 2010:73). It does emphasize that the Bank has little control of the execution process of its projects in Nigeria. 
Furthermore, the lack of greater involvement in project execution on the part of the African Development Bank was further compounded by its poor quality of technical and field manpower in Nigeria. The Bank had one of the fewest technical and field staff as international donor development institution in Nigeria. In fact, the AfDB has operated in Nigeria without a Field Office to coordinate its activities until last year, in February 2018. In 1987, when the Bank decided to establish field offices in a number of member-countries to add to its few regional offices, it only managed to open a small Liaison Office in Lagos that housed only seven personnel. Even when the liaison office later became the Bank Country Office in Nigeria, it was still very much unable to effectively co-ordinate its activities in the country in terms of mandate, resources, technical expertise and manpower. All important decisions to the activities of the Bank in Nigeria including project evaluation and audit, contracts and procurements, and disbursement of funds had to be referred to the Bank headquarters in Abidjan. As a result of lack of adequate number of technical and field staff, the Bank Country Office in Nigeria has always relied on desk reviews from the officials of the Nigerian Government with little or no recourse to field inspections. Most of the field assessment reports were prepared by the Nigerian Government's technical staff drawn from relevant ministries, department, and agencies \{MDAs\}. The implication is that the coordination of the AfDB field operations was largely left in the hands of the Nigerian Government and their contractual agents with little or no effective oversight from the Bank. The point is that the AfDB did not have adequate technical staff to monitor and supervise its field operations in Nigeria, and the situation constituted a serious challenge to the Bank as many of its projects in the country were poorly executed. 


\section{The External Financial Market and Other Principal Donors in Nigeria}

The African Development Bank lending operation in Nigeria, obviously, was partly constrained by the structure of international financial market. The AfDB had always had a great difficulty in mobilising enough resources on the foreign market to fund its project and non-project lending operations in member-countries of Africa. Though the Bank was able to mobilise fair amount of money on the international credit market in the 1980s and 1990s which saw a significant leap in its lending operations in Nigeria during the period, it has, however, found itself thrown into a difficult financial position with the sudden credit crunch in the Euro-American credit market due to the pervasive global economic and financial crises. The Euro-American credit zone, it is estimated, accounts for more than 80 percent of Africa's source of external financing (DAC, October 2014). The shrinking of foreign credit market, thus, meant a drastic fall in the percentage of financial resource inflow into Africa and, by extension, spelt more difficulties for the AfDB. Statistics shows that the net official development assistance, both on bilateral and multilateral arrangements, from the Organisation for Economic Cooperation and Development countries to Africa fell by more than 23 per cent between 2002 and 2012 (DAC, October 2014). The implication is that most of the activities of the Bank in Nigeria, as in many other countries of Africa, were starved with funds.

Aside the difficulty in mobilising finance on the external market, the African Development Bank, oftentimes, is confronted by poor commitment from other international counterpart donors in Nigeria. In cases where co-donors could not meet up with their own part of funding for projects, the bank found it rather difficult to underwrite the cost of the project alone. As a result, such 
projects were either delayed for long or abandoned, or, at best, poorly executed. This problem was most common in a number of the Bank projects in Nigeria that attracted counterpart funding from other international donors. For instance, the Bauchi-Gombe Rural Water Project signed in 2002 could not be completed in 2007 as agreed, and was abandoned due to the fact that the World Bank and the European Union stalled in their commitment to provide part of the required funding (Dikko, interview). The project ran into bad shape as the AfDB alone could not finance the entire cost of the project. The Nigeria-Benin Electricity Interconnection Project, also, suffered a similar fate. Since the AfDB signed for the project in 2002 with the European Bank, United States Agency for International Development and the Government of Norway as co-funders, only the bank had continued to provide its own funding for the multinational project. It was unfortunate that apart from the Norwegian Government release of 20 percent of its own counterpart funding in 2010, no serious commitment was made by any of the enlisted funders outside the AfDB (DAC, October 2014). The pace of the project has, thus, stagnated; thence, the AfDB funding of the project has become unsustainable and ineffectual. This problem partly explains why most of the counterpart projects embarked on by the Bank in Nigeria was not effectively executed.

In a similar vein, the African Development Bank activities in Nigeria were, oftentimes, overshadowed by the dominant influence of other principal donors especially the World Bank. Osagie (1998:27) posits that the political and economic clout that the World Bank, one of the Bretton-Woods institutions pushing the frontiers of Washington Consensus, has in Nigeria is undeniably dominant. The AfDB may hardly match such influence in the foreseeable future. The AfDB has ended up competing for 
bankable projects in Nigeria with other major international donors or financiers. Many of the sectors that the Bank extended its lending were the same sectors other principal donors identified as key areas of investment in Nigeria. In most cases, these other international donors were financially stronger and, supposedly, were to make huge commitments than the AfDB. For instance, in the areas of rural water supply, sanitation, and healthcare development, the AfDB has had to contend with the huge presence of the World Bank Group and, to an extent, the European Union in Nigeria. As Godfrey Obioma reported that while negotiation was still going on between Nigeria and the AfDB to secure a $\$ 300$ million loan for National Electric Power Authority, the World Bank showed interest in the project and appraised it for a $\$ 350$ million loan having allocated $\$ 1.5$ million as project preparation facility. The World Bank, even, shortlisted some consultancies from the United Kingdom-based Ewbank Preece, and Nukom Energy Company based in Lagos for the project (The Punch, July 1987). Also, the FADAMA I and II agricultural development programmes got funding interest not only from the AfDB but, also, from the World Bank, Food and Agriculture Organisation, United Nations Development Programme, and United States Agency for International Development. Situation like this, as described above, has made the potential impact of the AfDB lending in Nigeria go unnoticed. Put differently, the competition for bankable and profitable projects in Nigeria amongst international donors constituted one of the challenges that the AfDB faced in Nigeria. The table 1 below shows some counterpart projects assisted by the AfDB with other foreign donors in Nigeria. 


\section{Table 1: Some of the Counterpart Projects and Studies Undertaken by the AfDB in Nigeria with Other Donors}

\begin{tabular}{|c|c|c|c|c|}
\hline $\begin{array}{l}\text { Area } \\
\text { Covered }\end{array}$ & Project Description & $\begin{array}{l}\text { Total } \\
\text { Valued } \\
\text { Cost } \\
(\$ \mathrm{~m})\end{array}$ & $\begin{array}{l}\text { AfDB } \\
\text { Commitment } \\
(\$ \mathrm{~m})\end{array}$ & $\begin{array}{l}\text { Other } \\
\text { Partners }\end{array}$ \\
\hline National & $\begin{array}{l}\text { FADAMA Agricultural } \\
\text { Programme }\end{array}$ & 127 & 24.05 & $\begin{array}{l}\text { World } \\
\text { Bank/FAO/UNDP }\end{array}$ \\
\hline Multi State & Health Project I & 300.12 & 86.60 & WHO/USAID \\
\hline $\begin{array}{l}\text { Yobe/Bauc } \\
\text { hi States }\end{array}$ & Irrigation Project II & 203.5 & 96.08 & CIDA Canada \\
\hline Multi State & Water Project I \& II & 300.23 & 110.31 & World Bank \\
\hline National & ATASP-I & 430.10 & 115.25 & $\begin{array}{l}\text { World } \\
\text { Bank/USAID }\end{array}$ \\
\hline Multi State & $\begin{array}{l}\text { Health System } \\
\text { Development Project }\end{array}$ & 143.08 & 38.02 & $\begin{array}{l}\text { USAID/EU/ } \\
\text { WHO }\end{array}$ \\
\hline National & $\begin{array}{l}\text { Economic and Power } \\
\text { Sector Reform Project }\end{array}$ & 502.35 & 118.75 & $\begin{array}{l}\text { World } \\
\text { Bank/UK/Canada }\end{array}$ \\
\hline $\begin{array}{l}\text { Selected } \\
\text { States }\end{array}$ & $\begin{array}{l}\text { Rural/Urban } \\
\text { Supply and } \\
\text { Project }\end{array}$ & 455.27 & 116.46 & $\begin{array}{l}\text { World } \\
\text { Bank/USAID }\end{array}$ \\
\hline $\begin{array}{l}\text { Gombe } \\
\text { State }\end{array}$ & $\begin{array}{l}\text { Dadin Kowa Irrigation } \\
\text { and Hydro Power Project }\end{array}$ & 112.82 & 32.02 & World Bank \\
\hline $\begin{array}{l}\text { Cross- } \\
\text { River State }\end{array}$ & $\begin{array}{l}\text { Rural Access Mobility } \\
\text { Project }\end{array}$ & 171.87 & 44.75 & $\begin{array}{l}\text { China/CIDA } \\
\text { Canada }\end{array}$ \\
\hline Regional & $\begin{array}{l}\text { Nigeria-Benin Energy } \\
\text { Pool Integration Project }\end{array}$ & 214.70 & 81.05 & IDA/Norway \\
\hline Regional & $\begin{array}{l}\text { Enugu-Bamenda Road } \\
\text { Project }\end{array}$ & 261.50 & 148.71 & Denmark/Sweden \\
\hline
\end{tabular}

Source: Compiled from The African Development Bank Operation Reports, (various years up to 2014). 


\section{The Nigerian Society as the Big Suspect}

On the side of Nigeria, the government ineptitude and lack of commitment constituted one of the major challenges that have always militated against effective operation of the African Development Bank in the country. The Nigerian Government in most cases found it difficult to fulfill its part of the loan conditions. Both the Federal and States Government, oftentimes, were not able to provide the necessary counterpart funds required of them for execution of the Bank assisted projects. The delay or inability to provide these counterpart funds on the part of the Nigerian Government has led to late completion, cancellation, or/and abandonment of the Bank's projects in the country. For instance, the AfDB could not continue with the $\$ 123$ million loan approved for the Enugu Rural Electrification Project in 1992 when it became obvious that Enugu State Government was not ready to come up with its counterpart fund of $\$ 35$ million (Vanguard, September 2006). The consequence was that many of the rural electricity projects embarked on by the Bank in the State were abandoned. The Bank, also, had to opt for the cancellation of \$53 million loan for the Komadugu-Yobe Irrigation Project in 1994 not because lending was freezed to Nigeria under Gen. Abacha's regime but due largely to the government's unwillingness to commit its own part of the funding (Daily Times, August 1996). The implication of this lack of commitment on the part of the Nigerian Government is that a number of the AfDB assisted projects in Nigeria were belatedly and poorly completed and, at worst, either cancelled or abandoned. The table 2 below shows some of the severed Bank projects in Nigeria. 
Table 2: The AfDB Severed Projects in Nigeria as at December 1994

\begin{tabular}{|l|l|l|}
\hline S/N & Project/Programme & $\begin{array}{l}\text { Status (when } \\
\text { severed) }\end{array}$ \\
\hline 1 & Hadejia-Jamaare Valley Irrigation Project & Ongoing \\
\hline 2 & Second Line of Credit to NEXIM Bank & Ongoing \\
\hline 3 & River Basin Irrigation Planning Study & Ongoing \\
\hline 4 & $\begin{array}{l}\text { Agro- allied Resource Development } \\
\text { Intervention Loan }\end{array}$ & Ongoing \\
\hline 5 & $\begin{array}{l}\text { Reconstruction of Ibadan- Ilorin Highway } \\
\text { Project }\end{array}$ & $\begin{array}{l}\text { Awaiting } \\
\text { funds }\end{array}$ \\
\hline 6 & Komadugu-Yobe Irrigation Project & $\begin{array}{l}\text { Awaiting } \\
\text { funds }\end{array}$ \\
\hline 7 & $\begin{array}{l}\text { Lagos Fisheries Harbour Project } \\
\text { Awaiting } \\
\text { funds }\end{array}$ \\
\hline 8 & $\begin{array}{l}\text { Bank Note and Security Paper Mill } \\
\text { Project }\end{array}$ & $\begin{array}{l}\text { Awaiting } \\
\text { funds }\end{array}$ \\
\hline 9 & $\begin{array}{l}\text { Irrigation Project in Katsina } \\
10\end{array}$ & $\begin{array}{l}\text { Dadin Kowa Hydro- Electric and } \\
\text { Irrigation Scheme in Gombe } \\
\text { funds }\end{array}$ \\
\hline 11 & $\begin{array}{l}\text { Multi- State Road Project: covering } \\
\text { Adamawa and neighboring States of } \\
\text { Bauchi, Borno, Plateau, and Gombe and } \\
\text { Yobe. }\end{array}$ & $\begin{array}{l}\text { Awaiting } \\
\text { funds }\end{array}$ \\
\hline 12 & $\begin{array}{l}\text { Second Multi State Water Project } \\
\text { covering Akwa Ibom, Cross River, } \\
\text { Kwara, Osun, Imo, Sokoto, Taraba, } \\
\text { Adamawa and Kebbi States. }\end{array}$ & $\begin{array}{l}\text { Awaiting } \\
\text { funds }\end{array}$ \\
\hline
\end{tabular}




\begin{tabular}{|l|l|l|}
\hline 13 & $\begin{array}{l}\text { Rice Project covering Rivers state Rice } \\
\text { Development Project; Enyong Creek } \\
\text { Swamp Rice in Akwa Ibom; Middle } \\
\text { Rima Valley Rice in Sokoto. }\end{array}$ & $\begin{array}{l}\text { Awaiting } \\
\text { unds }\end{array}$ \\
\hline 14 & $\begin{array}{l}\text { Abia State Water, Sanitation and } \\
\text { Electricity (integrated) project }\end{array}$ & $\begin{array}{l}\text { Awaiting } \\
\text { funds }\end{array}$ \\
\hline 15 & $\begin{array}{l}\text { Second Multi State Health Project } \\
\text { covering Kaduna, Sokoto, Ondo, Cross } \\
\text { River, Ogun, Kebbi, and Edo States. }\end{array}$ & $\begin{array}{l}\text { Awaiting } \\
\text { funds }\end{array}$ \\
\hline 16 & $\begin{array}{l}\text { Education Support Grant to Federal } \\
\text { Ministry of Education }\end{array}$ & $\begin{array}{l}\text { Awaiting } \\
\text { funds }\end{array}$ \\
\hline
\end{tabular}

Source: Compiled from The African Development Bank Report, 1995.

Nigeria's poor commitment was, also, shown in the country's growing debt profile in the African Development Bank. The Nigerian Government, in the same vein, had found it pretty difficult to clear the loan arrears it owned to the Bank as debt. Okonjo-Iweala (2003) notes that the country has not been able to repay more than 50 per cent of the loans it contracted from the AfDB since the late 1980s. The country, thus, had battled with huge outstanding debts irrespective of its acclaimed leadership contributions in the Bank. The implication is that Nigeria has poor rating in terms of credit worthiness. The AfDB operation in Nigeria was further constrained due to the country's inability to meet the 'performance based allocation' lending condition of the Bank and, that has adversely affected the level of the Bank investment in Nigeria.

In a similar manner, the Federal and State Governments in Nigeria on several occasions had presented uncoordinated and poorly prepared project proposals in a bid to attract funds from 
international donors. The African Development Bank, no doubt, did not escape this dubious entanglement. Many a project proposed to the Bank by the Nigerian Government, especially the States Government, for funding were ill-fated $a b$ initio. Such projects, as dubious as they appeared, were not subjected to rigorous tests of technical soundness, financial viability, and contribution to poverty reduction. For example, in 2006, the Imo State Government used the Avutu Poultry Rehabilitation Project to secure a loan of $\$ 25.5$ million from the Bank (AfDB Group, 2014). Being one of the largest State owned farms in the southeastern part of the country, the Bank considered the loan investment worthwhile. However, it was shocking to find out that the funds were not committed in the said project, and never surfaced in the State budget until in 2014 when the Chinese Government showed interest for counterpart funding of the project. The only motivation was to use such projects to attract cheap funds; and when funds are granted, either those projects would not be executed as proposed and/or the funds meant for it would be diverted to other ulterior uses.

In another development, the high level of corruption in the Nigerian public life had largely undermined the operations of the African Development Bank in Nigeria. In most occasions funds voted for a project by the Bank were diverted to private purse by corrupt Nigerian officials. Sometimes, some officials in the executing federal or state agencies in Nigeria colluded with particular Bank officials sent to evaluate or audit the project. Lack of transparency and accountability often characterised the activities of officials and institutions handling the AfDB projects in Nigeria. As a result, a number of supervision and evaluation reports were complicitly doctored to cover some unaccounted funds or loot. For instance, an Audit Report released by the bank in September 2009, showed that the water projects it funded in Nigeria between 1991 
and 2007 were short-changed of about $\$ 280$ million by the activities of corrupt officials who were entrusted with the mandate to deliver those projects. In the case of Niger State Water Supply Project, the Bank officials on a monitoring and supervising mission colluded with some unscrupulous elements in the State Ministry of Water Resources to divert some of the funds that it was only the mobilisation fees was released to the contractors handling the project (AfDB Group, 2014).

The looting was not only restricted to water projects. With regard to the disbursement of soft loans to farmers, corrupt elements in the implementing Nigerian agencies often chose to favour their cronies and relatives at the expense of deserving and qualified public that the funds were meant for. In some cases, they devised surreptitious names and sureties to usurp the loans. In 2006, the Small and Medium Enterprises Department in the Bank of Industry was thoroughly overhauled resulting to the sack of four Desk Officers and twelve others because of lack of due process in the disbursement and monitoring of soft loans to micro, small and medium entrepreneurs (Nwako, interview). It was reported that between 2003 and 2010, 426 public officials in Nigeria were reprimanded and 98 of them were relieved of their duty due to financial misconduct involving counterpart project funds (FGN, December 2010). Thus, undue diversion of project funds to private purse was a major aspect of corruption in Nigeria that the AfDB had to contend with.

Apart from direct diversion of project funds amongst the Nigerian public officials, there was lack of transparency in the award of contracts for projects. Inflation of contracts and lack of due process in the procurement process was almost a routine. Corrupt officials often induce and co-opt with the contractors to over-bloat the cost of projects. In this way, huge sums of money 
were criminally lost to contract manipulations in the course of project execution in Nigeria. In 2005, Oby Ezekwesili reported that the Budget Monitoring and Price Intelligence Unit \{Due Process Office\} traced over $\$ 850$ million from inflated contracts between 2000 and 2004, and the figure was almost 30 per cent equivalent of the capital budget for 2004 fiscal year (Newswatch, July 2006). In fact, the misappropriated amount of money, quoted above, is a testament that the level of contract inflation and disregard of due process in the award of contracts in Nigeria was very alarming. Also, one Audit Report released by the African Development Bank in 2013 on its operations in Nigeria showed that contract manipulation and lack of due process in material and service procurement by some Nigerian officials and colluding local contractors alike unduly claimed more than 37 per cent of the total loan disbursements it made to the country between 2002 and 2012 (AfDB Group, 2014). The implication is that the Bank projects in Nigeria did not escape from Nigeria's culture of contract manipulations. This corrupt practice, thus, increased costs and, in some cases, stalled many of the Bank projects in the country as the actual funds committed could no longer defray the real cost of procurements.

Furthermore, the decision making process in the InterMinisterial Committee (made up of Ministry of Finance, Foreign Affairs, Justice, and other relevant ministries) of the Nigerian Government which was meant to co-ordinate the country's relations with the African Development Bank was largely characterised by unnecessary bureaucracy and delays. Such administrative bottleneck posed a huge challenge to the AfDB smooth operation in the country. Ogunjobi (2007:407) observed that African Development Bank Desk Officer responsible for Nigeria Trust Fund visited the country to follow up the approval of 
some projects for inclusion in the annual lending programme of the Bank after several correspondences without any response; and after one week of two unsuccessful attempts to hold the InterMinisterial Meetings for lack of a quorum, the officer returned to the Bank's headquarters in Abidjan without getting the approval. Needless to say that bureaucratic delay on the part of InterMinisterial Committee of the Nigerian Government, as very much related to poor project execution, constituted one of the challenges that the AfDB faced in Nigeria.

Moreover, local disagreements arising mainly from claims and counter claims for compensation before project takeoff by host communities was another challenge that the African Development Bank had to face in Nigeria. The problem has in one way or the other adversely affected speedy completion of many AfDB projects. In some extreme cases, the host communities physically obstructed on-going project construction. In March 2009, for example, the construction of rural road project assisted by the AfDB in Odukpani area of Cross River State was physically obstructed by the locals on the ground of non payment of compensation and the Slumberger Company workers handling the project had to leave the site. The construction work could not resume till after twenty (20) months (Okoro, interview). The level of vandalisation, loot, and threat that come with this physical confrontation most probably delayed the completion of the road project. In some other cases, there were several pending litigations bordering on local claim for compensation which has kept some of the Bank projects in Nigeria in abandoned state. The Port Harcourt Urban Water Rehabilitation Project which the Bank signed with the Rivers State Government in 2013, for instance, appeared to have been abandoned due to pending court cases bordering on compensations and contract status. The legal tussle, invariably, had 
stalled the execution of the project. The point is that these cases are considered as 'originating local matters'. They arose, in the first instance, due to the inability of the Nigerian Government to handle its own part of the lending agreement: to put in place the required institutional structures and interest resolution mechanisms that would guarantee smooth execution of the Bank projects in the country.

In the final but not in the least analysis, the African Development Bank and its activities in Nigeria have, largely, remained very unfamiliar to most Nigerians. Apart from respective government agents and few individuals who have had direct contact with the Bank, there is little knowledge and awareness of the bank and its activities in Nigeria. It is not surprising that Ogunjobi (2007:408) posits that 'there is considerable dearth of information on the activities of the Bank in Nigeria and Nigeria's role in the Bank. Put differently, the general lack of awareness amongst Nigerians about the AfDB, the very people it was established to serve, constitutes a serious challenge for the Bank. Most of the final beneficiaries of the AfDB activities in the country most probably do not even know that either the credit they got or infrastructural facilities they enjoy actually came from the Bank. Their understanding has always been that such benefactions were done to them were government statutory interventions. Besides, most of the Bank projects in Nigeria were administered by government ministries and agencies as the competent executing authorities. What the public know was that such interventions came from the Government, be it Federal or State Government. This situation has not helped the operation of the African Development Bank in Nigeria either. 


\section{Conclusion and the Way Forward}

Whichever way one may look at it, it is obvious that the responsibility for performance or/and failures of the African Development Bank operation in Nigeria do not rest squarely on the Bank alone. The problems largely associated with the Bank were inherited problems: it was not directly responsible for them. Some those problems claimed to have come from the Bank, rather originated from the international financial market structure. On the other hand, the Nigerian society hugely shares in the said responsibility for the failures of the Bank in the country. The AfDB operation in Nigeria is invariably hampered by the dysfunctions of the country's society, and not so much about the Bank's bourgeois approach to development or being a shadow of the World Bank in Africa. The Bank bourgeois orientation to development may not have been too inimical to Nigeria's development agenda if not that the fundamental structure of the country's society is hugely defective and dysfunctional. The problems that manifested in the course of the Bank operation in Nigeria due to the country's faulty society categorically ranged from inadequate funds, poor project execution due to delays and poor quality supervision, corruption, lack of public awareness, to local disagreements.

However, the success or failure of the African Development Bank in Nigeria in the foreseeable future would largely depend on how best these challenges are handled by both the Nigerian Government and the Bank. Nigeria, therefore, needs proper economic management culture and transparency in public offices. Administrative bottlenecks need to be removed in the process of policy execution. Nigeria, also, need to clear her debt of arrears it owned to the Bank. The question of emanating local disagreements needs to be properly handled with project host communities by the Nigerian authorities; thus, creating the 
enabling environment for the Bank to work efficiently. On the part of the African Development Bank, it needs to raise its field presence for its operation in Nigeria. This will go a long way to guarantee quality supervision of projects and programmes that the Bank has had to finance in the country. Also, the AfDB, like the World Bank and the European Union, should make itself to be more involved in the choice of projects to determine their economic viability and technical soundness before committing funds to the Nigerian officials and agencies. The participation of the Bank will ensure proper project preparation and evaluation. When these measures are taken heard of, they will go a long way to mitigate the challenges facing the AfDB in Nigeria.

\author{
Augustine Uche Igwe \& \\ Festus Chibuike Onuegbu \\ Department of History and \\ International Studies \\ Nnamdi Azikiwe University, \\ Awka \\ au.igwe@unizik.edu.ng \\ fc.onuegbu@unizik.edu.ng
}




\section{References}

Aluko, Olajide. (1990) "Oil Concession Prices for Africa: A Study in Nigeria's Policy Decision Making" in Olusanya, G.O. and Akindele, R.A. (eds) The Structure and Processes of Foreign Policy Making and Implementation in Nigeria, 1960-1990, Lagos: Nigerian Institute of International Affairs.

Daily Times, August 20, 1996.

Development Assistance Committee, (2014) Africa Aid Report, London: Oversea Development Institute, October.

Dibua, J. (2006) Modernisation and the Crisis of Development in Africa: the Nigerian Experience, London: Ashgate Publishing Co.

Dikko, Hassan. Interview, Abuja, July 19, 2017.

Ezekwesili, Oby. quoted in Newswatch, July 21, 2006.

Fordwor, K.D. (1981) The African Development Bank: Problems of International Cooperation, New York: Pergamon Press.

Knapp, Peter. (1994) One World-Many Worlds: Contemporary Sociological Theory, New York: Harper-Collins.

Mayhew, Leon H., ed. (1985) Talcott Parsons on Institutions and Social Evolution: Selected Writings, Chicago: University of Chicago Press.

New Nigerian, May 29, 1989.

New Nigerian, May 23, 1998.

Nwakor, Ben. Interview, Awka, September 3, 2017.

Obioma, Godfrey. "N805million ADB Loan for Nigeria" The Punch, July 20, 1987.

Ogunjobi, Olabisi.(2007) "Towards a More Effective NigeriaAfrican Development Bank Relations" in Akinterinwa, B. (ed.) Nigeria's National Interests in a Globalizing World: 
Further Reflections on Constructive and Beneficial Concentricism, Ibadan; Bolytag Publishers.

Okongwu, Chu. quoted in New Nigerian, May 29, 1989.

Okonjo-Iweala, N. (2003) "Managing Nigeria Debt: Institutional and Governance Aspects", in Okonjo-Iweala, N., Soludo, C.C. and Muhtar, M. (eds) The Debt Trap in Nigeria, Trenton, New Jersey/Asmara, Eritrea: Africa World Press, Inc.

Okonjo-Iweala, Ngozi. quoted in Daily Times, March 30, 2010.

Okoro, Remi-Callie. Interview, Calabar, August 11, 2017.

Osagie, Eghosa. (1998) "The Bretton-Woods Institutions and Africa", in Obiozor, G.A. and Ajala, A. (eds) Africa and the UN System: the First Fifty Years, Lagos: Nigerian Institute of International Affairs.

Pitt, Robert. (2010) Africa and the Politics of International Aid, London: Heritage Publishing Co.

Pope, Whitney. (1983) "Inside Organic Solidarity" American Sociological Review, Vol. 48, No. 5.

The African Development Bank, (1998) Agreement Establishing the African Development Bank, Abidjan: AfDB Group.

The African Development Bank, (2014) Operations Audit Report, AfDB Group.

The Nigerian Government, (2010) Budget Monitoring and Price Intelligence Report, December.

Vanguard, September 7, 2006. 